\title{
Suez Canal blockage: an analysis of legal impact, risks and liabilities to the global supply chain
}

\author{
Jade Man-yin Lee ${ }^{1}$, and Eugene Yin-cheung Wong ${ }^{1 *}$ \\ ${ }^{1}$ The Hang Seng University of Hong Kong, School of Decision Sciences, 6/F, Lee Quo Wei \\ Academic Building, Hang Shin Link, Siu Lek Yuen, Shatin, Hong Kong
}

\begin{abstract}
The global supply chain currently thrown into chaos due to the Suez Canal incident. On 23 March 2021, the Suez Canal, one of the most heavily used shipping routes, was blocked by vast container ship - the Ever Given. Affecting over 400 vessels scheduled to pass through the Canal in the East-West and West-East directions. Such vessels experienced a dilemma of the use of routes and schedules. Other victims included vessels that were scheduled to arrive at/pass through the Canal, shippers, consignees, ship operators, ship owners, and container terminals. About USD $\$ 15$ to 17 billion has been held up. This paper aims to reveal the potential damage caused to parties involved and examine the liability of parties involved. Specifically, the impact and legal consequences of the obstruction such as how the scope of general average applies as well as the possible solutions to minimise damage are discussed, followed by future developments. These results suggested that maritime transport support global supply chain linkages and economic growth, any disruption could bring huge impact and costs on various stakeholders along the supply chain. On this basis, the world should learn a lesson from this incident and the need for thoroughness prevention measure should be considered.
\end{abstract}

\section{Introduction}

World canals plays an important role in global trade. Construction of canals by developing more direct routes through land provides a shorter routing distance, less time and lower operating costs for vessels. The Suez Canal which is 120 miles long and about 205 metre wide started operating on 17 November 1869 [1]. It is an artificial trading waterway in Egypt, dividing Africa and Asia through the Isthmus of Suez connecting the Mediterranean Sea to the Red Sea [2]. It is a crucial channel for natural gas, transporting cargo and oil. The usage capacity of the Suez Canal in 2020 is massive, amounting to approximately 19,000 ships, or an average of 51.5 ships per day, with a net tonnage of 1.17 billion tonnes [2]. The Suez Canal is an important supply chain channel carrying $13.5 \%$ of the World's freight [3]. The Ever Given - the megaship which caused the Incident, is the largest cargo vessel in the world. It is owned by Japanese company - Shoei Kisen Kaisha [4]. The EverGreen, a

*Corresponding author: eugenewong@hsu.edu.hk 
Taiwanese shipping company, was the renter and operator of the vessel [4]. The vessel was managed by Bernhard Schulte Shipmanagement and consisted of a full Indian national crew (25 pax) [4]. It is 400 metres long with a width of 59 metres (193 feet) [4]. It can carry a maximum of 20,000 containers at a time [4]. At the time of the Incident, it was carrying 18,300 containers [4].

\section{Literature Review}

\subsection{Canal Blockage Impacts and Prospects}

Nowadays, sea transportation is ideal for transporting goods as ocean shipping offers substantial capacity and low prices for international trade. In 2015 , more than $80 \%$ of international trade was transported by ships [5]. Although the Canal blockage of Suez Canal has been cleared after the incident, it remains an ongoing effect on the global supply chain. More than 300 vessels were waiting to pass through the Canal during the blockage which stopped $12 \%$ of world trade from passing through the Canal [6]. The backlog of ships carried everything from cattle to crude oil given that almost USD $\$ 15$ to 17 billions had been held up [6]. This can be seen from the gas price on the day of the accident which had increased USD\$0.40 in the aftermath of the accident [7]. A further wilful effect for the later three to six months is likely [6]. Considering that ships keep coming into the canal, they have to queue at the back of the line given the backlog. Even if traffic has resumed, the backlog has created problems to container availability and ship availability. Countries like the US will experience less impacts than European and Asian countries since the US rely on routes through the Pacific to get goods to the west coast and the Panama canal to the east coast [7]. Though, the west coast routes will be hit by bottlenecks exacerbated by the current pandemic. As such, the US shippers are likely to find alternative routes, for instance air freight, or increase the use of Panama Canal in order to avoid bottlenecks. In contrast, the Suez Canal is the main artery for shipping between Europe and Asia [8]. In particular, the Suez Canal blockage has affected some major development strategies such as the "Belt and Road Initiative" adopted by China [6]. China, as the world's second largest economy, it heavily relies on import and export trade [5]. The Belt and Road Initiative strategy is a huge project with investments in 70 countries and international organisations [9]. It creates a maritime silk road connecting South China with Central Europe and the North Sea [10]. Remarkably, it runs via the Suez Canal. Following the blockage of Suez Canal, this strategy is completely affected by the traffic jam of Suez Canal. Hence, the obstruction shows that one ship can cause enormous damage to the world economy. Expectedly, there will be increase in pricing in the shipping industry especially on air freight pricing as some shippers shifted some of their shipments from sea to the already hectic airline capacity [8]. Since the Suez Canal is one of the five major checkpoints in the world, we may need to reassess the most efficient way to conduct global trade, especially, finding alternative routes.

Alternative routes to substitute the use of the Suez Canal are suggested (Nottebook, 2012). The routes of Suez Canal and Cape of Hope as substitution has considered the distance, transit time and generalised the cost from an origin to a destination for 11 major trade lanes [11]. The results revealed that the Cape of Hope route has the biggest potential to be an alternative to the Suez Canal route. Verny and Grigentin (2009) had evaluated the economic feasibility of the Northern Sea Route, Suez Canal and other multimodal transport alternatives. They observed that the Suez Canal and the Northern Sea lanes provide the least expensive transportation cost of moving goods [12]. Since every shipping company strives to optimise their profit with the lowest transportation cost, the Northern Sea route could also be an alternative route for shipping companies. 


\subsection{Critics over the Suez Canal}

The obstruction brings attention to the importance and effectiveness of the Suez Canal. There were critics over the Suez Canal since it began operating in 1869. The Canal is the key node in the international shipping network. Any blockage of this node will cause network variations to major shipping lanes. Therefore, companies usually focus on the costs, safety and geographical features when making decisions. It allows companies to evaluate the impact of canal comprehensively. The safety of the Canal is a crucial consideration in addressing operation and management of ships as maritime security guarantees ships the ability to sail through the Canal. Lu and Gao (2015) and Lu and Wang (2015) have assessed the safety situation and safety efficiency of the Suez Canal and concluded them poor [13][14]. Rupert found that the location of the Suez Canal presents challenges and vulnerabilities to its practical security [15]. Since it is located within a turbulent and fragile region, it was always targeted by terrorists during wars. Arguably, the monitor security of the Suez Canal is tight. There are multiple Egyptian military units armed with equipment stationed in the Canal zone. It consistently updates the troops and equipment comprehensively. The Canal is also covered by a range of surveillance. The coverage of CCTV is high with cameras situated at each signal station along the canal. Furthermore, the Suez Canal Container Terminal's security works closely with other law enforcement agencies to ensure the security of the terminal also applies to the nearby rivers and paths to the northern end. The way to access the terminal is also heavily guarded where positive identification must be present.

All shipping companies want to improve their transport efficiency and reduce cost. In the maritime industry, transportation costs are significant to shipping managers. Thus, companies are looking for the shortest route with the lowest cost. Clearly, longer shipping distances will increase the cost. However, it is not the sole factor influencing the costs. Factors such as cargo categories, ship type, sailing speed also need to be taken into account. Notably, the Suez Canal is known as one of the most reasonable shipping routes [5]. As cost is one of the most significant factors affecting the decision making of businesses, its lower cost compared to other routes is very ideal. However, many issues arise when the Suez Canal is blocked. If this is the case, the shipping routes will be longer likewise the transport cycle will also become lengthy. Many vessels have to abandon their original shipping route and deviate to the closest but lengthier route - the Cape of Hope, in order to avoid further delays. As a result, distances were increased by between 4000 and 6000 nautical miles and transportation expenditure increased around 4 to 5\% [5]. The blockage will also cause inflation to the container transportation cost. Considering Europe takes up the highest proportion of containers in world shipping trade at $23 \%$, the blockage will induce more than $10 \%$ increase in cost percentage per container [5]. Therefore, the greater increase in transportation costs reveals a bigger impact of the blockage.

In addition, there are several incidents at the Suez Canal over the years due to the dimensions of the vessels. The Suez Canal's length is about 193.3 kilometres with a depth of 28 metres and its widest point located at the Great Bitter Lake is only 133 metres wide [17]. The Suez Canal Authority (SCA) has set out limitations on a vessel's width and depth, however, there were no restrictions on the length of vessels. Instead, vessels over 400 metres long must getting permission from the SCA before navigating the Canal. Yet, many largest cargo vessels in service are 400 metres long [18] like the Ever Given which was stranded in the Suez Canal in 2021, has a Suezmax size of 399.9 metres long [19] that just fits within the limit set for the Canal. With the capacity to carry 20,000 containers, the Ever Given is unlikely to stop suddenly. So, when operating the Suezmax within the narrow margins, the skipper has to maintain the speed steadily in order to keep the vessel steering effectively. The process to salvage and refloat such vessels is complicated. It requires specialised instruments and could be time-consuming depending on the severity of the 
grounding [20]. Hence, this makes a blockage like this almost unavoidable, particularly because the ship's length far exceeds the canal's width.

\subsection{Legal aspect}

Apart from the operation and management of the ship, the legal rights and potential legal disputes on the canal blockage are evaluated as intensive lawsuits and challenges would be encountered by various stakeholders along the supply chain. The principles governing the shipping industry is dictated by the law of the sea or maritime law. The former law applies internationally while the latter refers to domestic shipping law. These laws play a crucial role in solving disputes between parties.

\subsubsection{The implication of a contract of affreightment}

A contract of affreightment refers to an agreement allowing the cargo owner to enforce the shipowner himself or through an agent to transport goods by sea. Such agreements may take various forms. The most common forms are the charterparty and bill of lading. A charterparty is a contractual agreement between the shipowner and the charterer for the use of vessel entirely or partially [21]. A billing of lading is an agreement between the carrier and the shipper of goods [21]. It outlines the details of goods to be shipped including type of goods, destination and quantity etc.

All contract of affreightment has a mandatory framework, the Hague-Visby Rules, that set out minimum responsibilities, liabilities, rights and immunities of carriers. Outside the Hague Visby Rules, parties are free to negotiate additional terms under the principle of freedom of contract. The additional terms could be expressed or implied. In the course of business, terms are usually expressly written in the contract. Sometimes, such terms might strike down the minimum liability as provided under the Hague Visby Rules. For instance, a bill of lading incorporates the Hague Visby Rules illustrating that the vessel cannot deviate from voyage. However, parties included a term in their contract stating that "Where a carrier is affected by grounding, he therefore will not be liable for deviate from the usual route.". In such case, the parties' term prevails the Hague Visby Rules and the carrier is not in breach of contract.

Noticed that some vessels navigated to alternative routes in order to meet deadlines following the Suez Canal blockage incident. However, it might have an unexpected consequence. In Société Franco Tunisienne d'Armement v. Sidermar S.P.A [22], the shipowner chartered the vessel to the charterparty for the purpose to sail goods via Suez Canal. Later, the suez canal announced closure of the canal. The shipowner asserted that the vessel can navigate via alternative route, the Cape of Hope which can also reach the same destination and wanted to increase freight charge while the charterparty claimed that the contract is frustrated. The court concluded that the contract was frustrated and the alternative route is circuitous, unnatural and different in a variety of ways from the original route. Applying to the Suez Canal blockage, if the alternative routes navigated is too absurd from the original purpose and routes, it might cause frustration to the contract. Frustration to contract means the vessel operator is liable for the breach of contract. The cargo owners will then be able to sue the vessel operator for absurd deviation and the operator will not be able to restitute from the extra transportation expenditures.

\subsubsection{The application of laws}

As a contract of affreightment relating to international sales of goods, this inevitably raises issues to the applicable law over the contract since rights and obligations are different 
in different legal systems. Although maritime law has developed internationally, a contract usually operates under the laws of an individual country. Remarkably, outside of the Hague-Visby Rules, parties can freely negotiate additional terms following their wishes. Hence, most contracts will contain an express term regarding to the choice of law. This practice has long been customary for parties entering into contracts of affreightment to prevent any argument relating to the choice of law which governs the contract. For instance, a contract is about to co-signed by one party located at Netherland while another in China. Before the contract is formed and signed, it is essential for them to demonstrate which country's law they will use in order for them to incorporate rules of that country into the contract.

\subsubsection{The role of maritime insurance}

Today, parties usually collaborate with maritime insurance in settling claims hence it plays an essential role in the shipping industry. It is a contract between the insured and the insurer by means of protection and indemnity against a consideration to be paid by the insured in the form of a specific premium. The insurance is applicable to the perils of sea as well as risks relating to cargo, ship and freight such as loss of cargo or cargo damage in which goods are transferred between an origin and a final destination. This guarantees the safety of the ship and the safe arrival of goods.

Maritime insurance is classified into 3 categories, namely, Hull insurance, Machinery insurance and Protection and Indemnity (P\&I) insurance. The Hull insurance covers damage to the vessel while the Machinery insurance compensates all essential machinery of the ship [23]. Lastly, the P\&I insurance protects risks connected with ownership of the vessel and risks related to the hiring of the ship such as crew related claims and cargo related claims [23]. P\&I insurance is a mutual insurance association providing shipowners a risk pool through mutual maritime insurance. It covers the liabilities to third parties and risks which are not covered elsewhere in the hull and machinery insurance and other policies [23].

\subsubsection{Unique insurance coverage to maritime industry - General Average}

General average is an example of P\&I insurance. It is a principle peculiar to maritime law. It is an international regulation, and it aims to preserve a vessel or a life from a dangerous situation in an emergency. Hence, a vessel or life must be saved in order to declare a general average. It compels parties involved to share any losses occurred from voluntary sacrifice in the event of an emergency. Damage to the hull while attempting to refloat is an example of sacrifice. In contrast, if the entire vessel is lost then it cannot be declared as a general average.

Essentially, general average has nothing to do with contract of affreightment. However, in the 14-15th century, the invention of contract propose the general average to be implemented into the contract [24]. Thus, in the late 19th century, the York-Antwerp Rules were adopted to uniform the principle of general average [24]. The York-Antwerp Rules have set out what losses and expenses are admissible in general average and how general average is to be apportioned between parties [24]. Therefore, in most cases today, general average is usually incorporated into charterparties or bills of lading. Hence, whether a party is liable to another will subject to contractual clauses.

A general average expenditure includes the cost of discharging cargo to refloat the vessel and hiring of tug to assist with the refloating of vessel. To define the general average contribution, the shipowner needs to appoint a general average adjuster to determine the cost incurred by each involved party. 
A general average adjuster is an expert on maritime insurance and general average. He or she has the duty to confirm the general average amount. In order to calculate the total, he or she has the duty to examine documents such as assess cargo manifest, bill of lading and deposit receipts in order to find out what is allowed under the general average, contributory values and allowances. The shipowner may discharge the general average sacrifice by cash deposit, signing of Lloyd's Average Bond backed by bank guarantee or through its P\&I club or similar institution guarantees. This means in cases where the shipowner sustains losses due to a sacrifice e.g. delay of vessel, all parties who were concerned with the safe arrival of the ship such as the charterer, shipowner, cargo owner will contribute to these losses. The contribution may be covered by institutes like the P\&I club which is a nonprofit co-operative formed by shipowners where each member contributes a certain amount to a common risk pool. Therefore, such losses could be covered fully or partially by the P\&I club.

\subsubsection{Latest judgment of other accident in the Suez Canal}

There was a collision incident in the Suez Canal on 15 July 2018 [25]. Suffered from engine failure, the vessel at the head of a convoy, AENEAS was halted in the canal [25]. Contingency plan to moor the vessels in the queue behind was taken. During the mooring operation, PANAMAX ALEXANDER collided with SAKIZAYA KALON [25]. Subsequently, these two vessels collided with OSIOS DAVID [25]. The issue arises on who is liable to the collision. On 5 October 2020, the case finally presented to the Court. The Court held that the PANAMAX ALEXANDER provided opportunity for later collision therefore is responsible and liable for the causation. Whilst there was nothing SAKIZAYA KALON and OSIOS DAVID could do to avoid the incident hence they are not liable to the collision [26].

Overall, it will depend upon the investigation outcome and takes ages to solve the entire issue. Whether the insured could claim against its insurer successfully will depend upon the policy features. The incident must also happen within the policy period.

\section{Suez Canal Incident}

At around 07:40 EGY (05:40 UTC) on 23 March 2021, the Ever Given was enroute from Malaysia to the Netherlands (Fig. 1) [2]. Weather forecasts revealed that the winds on that day were strong where they reached $40 \mathrm{kn}(74 \mathrm{~km} / \mathrm{h} ; 46 \mathrm{mph})[2]$. While the Ever Given was crossing the southern end of the canal, the force of the strong wind caused the head of the vessel to deviate, leading it off course and being stuck on the southern canal [27].

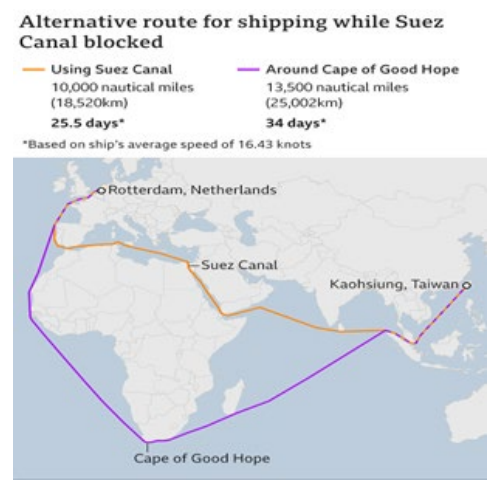

Fig. 1. Alternative routings for ship liners during Suez Canal Blockage. 


\subsection{Recovery Action}

In the aftermath of the Incident, the SCA's collaborated with Dutch Company - Royal Boskalis Westminster's subsidiary - SMIT Salvage to carry out marine rescue operations immediately (Fig. 2) [28]. In the beginning, the owner of Ever Given cooperated with Lloyd's Open Form in an attempt to refloat the vessel [2]. Tugboats were used to tow Ever Given together with an excavator to remove sediments beneath the bow of the Ever Given (Fig. 3) [29].

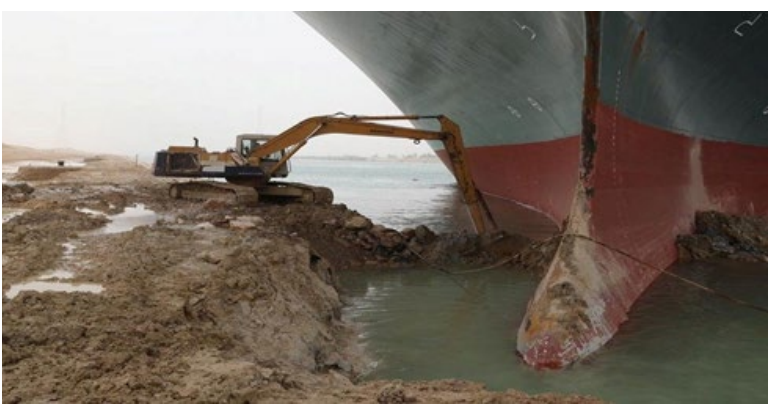

Fig. 2. Marine rescue operations on Ever Given [4, 5].

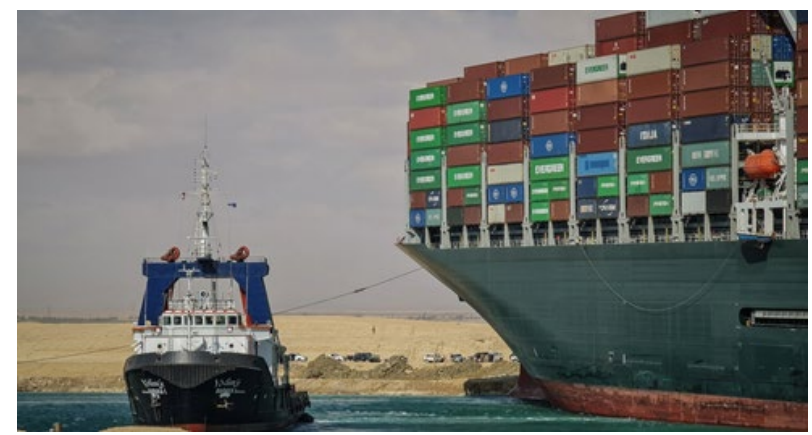

Fig. 3. Tugboats towing Ever Given.

Meanwhile, some affected ships took a 3,000 miles detour to Africa's Southern tip - the Cape of Good Hope [30]. The alternative route is lengthy. The journey added more fuel costs and took additional two to three weeks to complete [30].

On 28 March 2021, Ever Given made an announcement saying they were working on the dredging operation and more than 20,000 tons of sand and mud had been removed successfully, loosening the vessel's bow within the bank of the Canal [31]. Also, the engineer had taken advantage of high tide to make Ever Given refloat [31].

On 29 March 2021, Ever Given was finally freed. Engineers took advantage of high tide plus the pulling power of 14 tugboats to refloat Ever Given eventually [28]. To examine the cause of the Incident, Ever Given had begun towing north to the Greater Bitter Lake for further investigation. Soon afterwards, the maritime traffic resumed and 450 ships gradually and successfully passed through the canal [28]. Meanwhile, approximately 400 ships were still awaiting to pass through the Canal in the Red Sea, Mediterranean Sea and the Great Bitter Lakes [28].

On 1 April 2021, the owner of Ever Given declared a general average as a result of the refloating work, which means that shippers would be expected to share the costs of the ship's rescue [32].

On 3 April 2021, the backlog of ships postponed by the disruption was finally cleared [32]. 
On 12 April 2021, the Egyptian Government demanded \$1 billion in compensation to have the Ever Given released from the Great Bitter Lake. The Ever Given refused and the vessel is still being held up by the Egytian government. Despite that Ever Given refloated, the blockage effect over the global supply chain continues [33].

\subsection{Impact}

Available logistics is one of the presumptive designs of the global supply chain with the focus on price negotiation with an assumption on availability and reliability. Since global trade was interrupted by Ever Given, global supply chains are heavily affected and will remain blocked until the Ever Given gets back on track. The impacts include impacts on logistics operations, legal and insurance with parties not limiting to the carrier, shipper, terminals, charter party and insurers.

Before the Incident, the COVID-19 pandemic had caused a serious setback for the maritime industry. The cost of shipping has doubled since the virus outbreak. The Suez Canal Incident is putting greater pressure on global trade. The blockage leading to a huge congestion of over 370 ships at the Suez Canal. Vessels of all types were forced to wait for the obstruction to clear in order to pass through the Canal. The blockage had caused disruption to deliver over $\$ 9$ billion worth of goods each day which is equivalent to $\$ 400$ million worth of trade per hour [34]. Since it had been stuck for over 6 days, approximate $\$ 54$ billion trade loss had been estimated [35].

In conjunction with trade loss, the actual economic damage around the world could be even higher considering essential commodities including oil and gas may be in interim shortage as a result of the blockage. According to Allianz, a German insurer, the obstruction could diminish global trade growth by 0.2 to 0.4 annually [35]. Subsequently, prices for some commodities or goods may be inflated. Companies may even incur additional expenditure such as shipping delays compensation and rising commodity prices.

According to Fitch Ratings, the insurance sector will also suffer over approximately USD \$31 billions loss since insurers are liable to compensate victims, namely companies, customers, other vessels companies etc [36]. Hence, insurers will face a great number of claims. Companies and law firms are also expecting to bring extensive lawsuits regarding cargo interests to courts. Such claims would likely focus on the delay and disruption caused by Ever Given. The damages that can be claimed will depend on the economic loss, damage to freighter and additional expenses incurred. However, it is hard to draw a line on the damage suffered. Thus, the issue would not be solved until all the cases are settled. As a result, the impact on the global supply chain may last longer than months, potentially for years.

As regards to political impacts, the blockage has stopped many countries' plans since Suez Canal is a major shipping lane connecting Europe and Asia. This brings about significant hurdles to global infrastructure development, "One Belt One Road" adopted by China [6]. In this globalised world, many items like mobile phone are completed with components from multiple different countries. The delay caused by blockage will affect the manufacturing industry as well. Since the delay will affect components to be delivered on time, potentially, it might cause components shortage, eventually delaying factories to compose components together. Thus, there is going to be a challenge to get customers what they want.

Although Ever Given was freed, it is believed that the domino effect of the Suez Canal blockage is vast and will last for several years.

\subsection{Further Investigation and Possible Outcomes}


In order to discover the causes of the Incident, investigations of seaworthiness and Ever Given Captain's action would be conducted. Hence, Ever Given will remain in the Great Bitter Lakes area till the inquiries are over. it is expected that the inquiries will last for a maximum of four days. Egypt has conducted its own examination including interviewing the captain and crew and reviewing the data record in the "black box" of Ever Given [37]. As the registry of Ever Given, Panama's Maritime Authority also carried out its own probe [38]. If the investigation results are contradictory, the cases will become much more complicated.

Some believe that the weather was the cause of the Incident though the reason may not be that straightforward, given that the ships behind Ever Given did not run into similar troubles as the propulsion engines with rudders run by ships are nearly identical and similar. Software and human errors may be variable factors. As noted by the manager, Bernhard Schulte Shipmanagement that was responsible for the crew, thus, if this is the case, the operator, EverGreen would be able to sue it for failure to manage Ever Given reasonably.

As noted that the Ever Given has been grounded by the SCA for fining, there are battles between the shipowner insurer and the SCA. The SCA blamed the Ever Given Captain for sailing too fast while the UK club argued that the convoy was controlled by the SCA pilots and the SCA vessel traffic management services including control of ship's sailing speed and the availability of escort tugs [39]. The case is currently awaiting for the final verdict on compensation which will be set on 20 June 2021 [39].

\subsection{Potential Claims and Losses}

The shipowner is liable for the damage caused as well as damage caused to third parties. The UK P\&I Club is the insurer of the owner of Ever Given. The insurance covers certain third party liabilities, shipowning expenses and expenses arising from operating ships. Considering the Incident, the P\&I Club has to pay damages for damage caused to the Suez Canal. Additionally, it might need to recover the shipowner from the paid declared general average after the grounding of Ever Given. It is also liable to compensate victims (e.g. companies and other canal users) who suffer from cargo damage, loss of market, business interruption. It also has to compensate the loss of revenue of the SCA and possible fine from the SCA.

As a renter and operator of Ever Given, EverGreen is responsible for all the goods on board. Since it has the Charterer's Liability Insurance, its insurer, TT Club is responsible for reimbursing the general average and salvage to all the partners involved with EverGreen. This covers all containers and fuels on board. Whether the partners could claim or not will depend on the contractual liabilities. Besides, EverGreen may have to deal with potential consortium claims. Consequently, EverGreen itself will undergo loss of goodwill.

During the investigation, there is an ongoing negotiation between the SCA and the owner, insurer and operators of Ever Given. On 13 April 2021, the Court ruled that USD $\$ 16$ million damages were to be awarded to the SCA and granted it a warrant to seize Ever Given following the unsuccessful negotiation between them [33]. The SCA emphasised that it will hold up the ship until roughly USD \$1 million damages are paid [33]. Meanwhile, the goods on board are stranded and cargo owners are facing additional expense, delay and customer complaints. Further challenges are faced by the operator of Ever Given. It might need to unload the 18,000 goods-filled containers to other vessels [33].

Maritime Law indicates that in huge casualty events, cargo owners on board a ship should contribute to the rescuing cost. The 2018 fire on the Maersk Honam is an example where the cargo owners were subjected to pay off fixed sums amounting to $54 \%$ of cargo value in order to release their cargo [40]. Applying to this case, this means that the 
container owners on board Ever Given may need to pay an additional cost to have their cargo released.

Bernhard Schulte Shipmanagement, the technical manager of Ever Given was in charge of its operation [33]. It has the obligation to ensure the crew handle Ever Given without fault. In case that investigation finds that that the crew was in fault, the operator will have the right to claim damages from Bernhard Schulte Shipmanagement. Except if the Bernhard has purchased the professional Indemnity Insurance, it would be settled by the insurer.

Other affected charterers may want to seek indemnity for cargo damage and late delivery charge from the shipowner. Notably, in place where Hague-Visby Rules apply, it would be unsuccessful to claim for pure economic loss. However, this could be exempted by contractual terms and other rights may be granted. Therefore, whether such claims are allowed or not will be based upon the terms and place the contract was signed.

\subsection{Solutions}

There is a history of disruption to the Suez Canal. In 2004, the Suez Canal shut down for 3 days due to an oil tanker ship, MT Tropic Brilliance got lodged sideways [41]. Another disruption was found in 2007 where the OOCL Japan vessel was stuck perpendicularly causing the Suez Canal to be closed for a few hours [41]. More incidents were found in the year of 2018 and 2020. Learning from these unfortunate blips, parties could minimise the damage by considering the following.

The above revealed that the Egypt Government is compelled to consider further development of the Suez Canal. Considering that the channel of the Suez Canal is not wide enough for big ships to pass through like the Ever Given, it might want to widen the Suez Canal channel. The SCA should implement a set of contingency plans along with regular manoeuvre. It may interconnect with other countries in such events as well. It should also review ways vessels travel through the Suez Canal by implementing maritime traffic controls such as setting limits on vessel speed, length, weight and height or number of vessels pass through the canal at the same time.

As to the owner and operator of Ever Given, they should send engineers to scrutinise the vessel regularly and before it sails in order to ensure the vessel is good to go. To further protect themselves from legal action, they should ensure their insurances are well covered for such huge casualty events.

Since the Suez Canal incident revealed how fragile the channel between Europe and Asia is and prompted international effort to discover alternative maritime routes. It gives charterers and containers users a good opportunity to explore other routes or forms of transportation as a backup plan. The use of the North Sea Corridor could be an alternative scheme. The "International North-South Transport Corridor (INSTC)" project has been created by Russia, Iran and India since 2002 [42]. Recently, the member states are planning to expand the seaway to a $7,200 \mathrm{~km}$ long route connecting Mumbai to Moscow [43]. This will accelerate trade activities between Europe and Asia. It is likely to reduce travel times by 20 days and save at least 30 percent shipping costs compared to the Suez Canal [44]. Apparently, the Northern Sea Route has the potential to become another primary chokepoint for the Maritime industry. Nevertheless, whether it could be formed will depend on the foreign affairs between the member states. The future development of this is one to pay attention to. 


\section{Conclusion}

Undoubtedly, the Suez Canal Incident has disrupted the global supply chain. Exposed to such disruption to the global supply chain and experienced in surging prices on goods like oil and gas due to the incident, it demonstrated the need to review the way global trade is being conducted. In case such an event reoccurs, contingency plans should be implemented interstate. To minimise loss, companies should take immediate action to resolve both short term and long-term issues. Companies may consider the use of other chokepoints like the Panama Canal and Northern Sea Route. Evidently, incidents like the Suez Canal are unavoidable, companies should therefore reflect upon the crisis and raise their awareness for their future development.

\section{Reference}

1. Suez Canal, Egypt. (2021). Earth Watching. https://earth.esa.int/web/earthwatching/image-of-the-week/content/-/article/suez-canal-egypt

2. BBC News. (2021, March 24). Egypt's Suez Canal blocked by huge container ship. https://www.bbc.com/news/world-middle-east-56505413

3. Cecere, L. (2021, March 29). The Ever Given Is Moving But Your Supply Chain Will Not. Forbes. https://www.forbes.com/sites/loracecere/2021/03/29/the-ever-given-ismoving-but-your-supply-chain-will-not/?sh=1 cef5b92744f

4. BBC News. (2021, March 25). Suez Canal: Owner of cargo ship blocking waterway apologises. https://www.bbc.com/news/world-middle-east-56522178

5. Gao, T., \& Lu, J. (2019). The impacts of strait and canal blockages on the transportation costs of the Chinese fleet in the shipping network. Maritime Policy \& Management, 46(6), 669-686. https://doi.org/10.1080/03088839.2019.1594423

6. Duerr, G. M. E. (2021,March 30). Suez Canal Blockage: Ship Freed, Heavy Traffic, International Impact. DigitalCommons@Cedarville University. https://digitalcommons.cedarville.edu/history and_government_media_contributions/1 $\underline{231}$

7. LeBlanc, J. (2021). Suez Canal Blockage: Ripple Effect on Miami Valley Supply Chain.https://digitalcommons.cedarville.edu/business_administration_media_contributi ons $/ 120$

8. Kickham, V. (2021, April 1). Supply chains brace for ripple effects of Suez Canal blockage. DC Velocity. https://www.dcvelocity.com/articles/50093-supply-chainsbrace-for-ripple-effects-of-suez-canal-blockage

9. Week In China. (2016, November 1). What is Belt and Road? https://www.weekinchina.com/chapter/belt-and-road/what-is-belt-and-road/

10. Belt and Road Initiative. (n.d.). Belt and Road Initiative. Retrieved May 3, 2021, from https://www.beltroad-initiative.com/belt-and-road/

11. Notteboom, T. E. (2012). Towards a new intermediate hub region in container shipping? Relay and interlining via the Cape route vs. the Suez route. Journal of Transport Geography, 22(2), 164-178. https://doi.org/10.1016/j.jtrangeo.2012.01.003

12. Verny, J., \& Grigentin, C. (2009). Container shipping on the Northern Sea Route. International Journal of Production Economics, 122(1), 107-117. https://doi.org/10.1016/j.ijpe.2009.03.018 
13. Jing, L., \& Wang, S. (2015). Safety Evaluation of China's Maritime Transport Key Nodes. Journal of Transportation Systems Engineering and Information Technology, 15(1), 30-36. http://en.cnki.com.cn/Article en/CJFDTotal-YSXT201501007.htm

14. Jing, L., \& Gao, T. H. (2015). Efficiency of safety control in key nodes of international sea lanes. China Soft Science, 10(1), 1-8. https://doi.org/10.3969/j.issn.1002$\underline{9753.2015 .10 .001}$

15. Rupert, H. (2009). The Suez Canal: Strategic \& Operational Security Realities - Past, Present, \& Future. Strategic Insights: Global Maritime Analysis, 19(1), 1-6. https://www.sldinfo.com/wp-content/uploads/2009/11/Securing-the-Suez-CanalOctober-20091.pdf

16. Canal Characteristics. (n.d.). Suez Canal Authority. Retrieved May 6, 2021, from https://www.suezcanal.gov.eg/English/About/SuezCanal/Pages/CanalCharacteristics.as pX

17. Park, N. K., \& Suh, S. C. (2019). Tendency toward Mega Containerships and the Constraints of Container Terminals. Journal of Marine Science and Engineering, 7(5), 131. https://doi.org/10.3390/jmse7050131

18. Vessels Details. (n.d.). American Bureau of Shipping. Retrieved May 6, 2021, from https://www.eagle.org/portal/\#/absrecord/details

19. Hopcraft, R. (2021, March 26). Commentary: Why the Suez Canal accident is a worstcase scenario for global trade. CNA. https://www.channelnewsasia.com/news/commentary/suez-canal-container-shipaccident-global-trade-14486954

20. Baughen, S. (2012). Shipping Law (5th ed.). Routledge.

21. Société Franco Tunisienne d'Armement v. Sidermar S.P.A [1960] 3 W.L.R. 701

22. Gürses, Ö. (2017). Marine Insurance Law (2nd ed.). Routledge. 1-460

23. Wilson, J. (2010). Carriage Of Goods By Sea (7th edition). Longman. 1-559[42] Baghirov, O. (2021, April 18). Suez Canal Shutdown revealed the importance of the Middle Corridor. Modern Diplomacy. https://moderndiplomacy.eu/2021/04/18/suezcanal-shutdown-revealed-the-importance-of-the-middle-corridor/

24. Owners of the Vessel Sakizaya Kalon v Owners of the Vessel Panamax Alexander. (2020). National University of Singapore. https://cmlcmidatabase.org/owners-vesselsakizaya-kalon-v-owners-vessel-panamax-alexander

25. Sakizaya Kalon (2020). Owners of The Vessel v Panamax Alexander, Owners of The Vessel [2020] EWHC 2604 (Admlty)

26. Farrer, M., \& Safi, M. (2021, March 24). Giant ship blocking Suez canal partially refloated. The Guardian. https:/www.theguardian.com/world/2021/mar/24/hugecontainer-ship-blocks-suez-canal-evergreen

27. Schuttevâer, M. L. D. (2021, March 29). Suez Canal unblocked: "We pulled it off!" GlobeNewswire.

https://www.globenewswire.com/newsrelease/2021/03/29/2200887/0/en/Suez-Canal-unblocked-We-pulled-it-off.html

28. Check, R., \& Journalism, V. (2021, March 29). Suez Canal: How did they move the Ever Given? BBC News. https://www.bbc.com/news/56523659

29. Talmazan, Y. (2021, March 30). Suez Canal is open again, but impact of Ever Given saga will be felt for some time. NBC News. https://www.nbcnews.com/news/world/suez-canal-open-again-impact-ever-givenblockage-will-be-n1262453

30. BBC News. (2021, March 28). Suez Canal: Effort to refloat wedged container ship continues. https://www.bbc.com/news/world-middle-east-56547383

31. Leonard, M. (2021, April 8). Ever Given, general average and why shippers will share the costs of a ship's rescue. Supply Chain Dive. https://www.supplychaindive.com 
32. Schuler, M. (2021, April 14). Ever Given Updates from the Ship Manager - Ship Arrest 'Extremely Disappointing.' GCaptain. https://gcaptain.com/ever-givengrounding-the-latest-from-the-ship-manager/

33. Dzhanova, Y. (2021, March 29). The Suez Canal has a contentious history and has been blocked and closed several times since opening. Insider. https://www.businessinsider.com

34. Das, K. (2021, March 30). Explained: How much did Suez Canal blockage cost world trade. India Today. https://www.indiatoday.in/business/story/explained-how-much-didsuez-canal-blockage-cost-world-trade-1785062-2021-03-30

35. Suez Canal Blockage a Large Loss Event for Global Reinsurers. (2021, March 29). Fitch Ratings. https://www.fitchratings.com/research/insurance/suez-canal-blockagelarge-loss-event-for-global-reinsurers-29-03-2021

36. Egypt's Suez Canal Authority reveals how MV EVER GIVEN went aground, holds shipmaster responsible for the accident. (2021, May 31). EgyptToday. https://www.egypttoday.com/Article/1/104488/Egypt $\%$ E2\%80\%99s-Suez-Canal-

Authority-reveals-how-MV-EVER-GIVEN-went

37. Egyptian Investigators Kick Off Probe in Suez Canal Blockage. (2021, March 31). GCaptain. https://gcaptain.com/egyptian-investigators-kick-off-probe-in-suez-canalblockage/

38. Chambers, S. (2021, June 4). Suez Canal Authority to blame for Ever Given's high speed: UK P\&I Club. Splash247. https://splash247.com/suez-canal-authority-to-blamefor-ever-givens-high-speed-uk-pi-club/

39. Hochfelder, B. (2018, May 22). Shippers will foot more than half the bill to recover cargo after Maersk fire. Supply Chain Dive. https://www.supplychaindive.com/news/maersk-honam-fire-cargo-risk-shipperpayment/524076/

40. koh, A., Wardany, S. E., \& Clark, A. (2021, March 24). Suez Canal Snarled by Giant Ship Choking Key Trade Route. Bloomberg. https://www.bloomberg.com/news/articles/2021-03-23/suez-canal-traffic-blocked-bycontainer-ship-stuck-in-waterway

41. Sahakyan, M. (2020, September 17). Rebuilding Interconnections: Russia, India and the International North-South Transport Corridor. AsiaGlobal Online. https://www.asiaglobalonline.hku.hk/rebuilding-interconnections-russia-india-andinternational-north-south-transport-corridor

42. Baghirov, O. (2021, April 18). Suez Canal Shutdown revealed the importance of the Middle Corridor. Modern Diplomacy. https://moderndiplomacy.eu/2021/04/18/suezcanal-shutdown-revealed-the-importance-of-the-middle-corridor/

43. Business Insider India. (2021, April 5). Suez Canal issue reprised interest in the North South Corridor being built by India, Russia and Iran as an alternative. https://www.businessinsider.in/business/news 